УДК 347.73

DOI https://doi.org/10.32849/2663-5313/2021.5.27

\title{
Надія Пришва,
}

докт. юрид. наук, професор,

професор кафедри фінансового права

Київського начіонального університету імені Тараса Шевченка

\section{ДИСКУСІЙНІ ПИТАННЯ ЩОДО ПРАВОВОГО РЕГУЛЮВАННЯ НЕПОДАТКОВИХ ОБОВ'ЯЗКОВИХ ПЛАТЕЖІВ ДО ПОЗАБЮДЖЕТНИХ ФОНДІВ КОШТІВ}

У статті розглядаються неподаткові обов'язкові платежі до позабюджетних фондів коштів, визначаються їх види. Особливу увагу приділено платежам, які в наукових джерелах отримали назву «парафіскалітети». До останніх відносять встановлені державою обов'язкові платежі, що зараховуються до фондів коштів юридичних осіб публічного чи приватного права, що залучені державою до реалізації публічних функиій економічного та сочіального спрямування. Розглянуто правову природу платежів до Фонду гарантування вкладів фізичних осіб, винагороди (відрахування) для компенсащіі втрат правовласників від приватного копіювання, плати за розподіл газу тощо. 3'ясовано місие иих платежів у системі публічних доходів. Розглянуто питання доходів квазіпублічних фондів коштів, підстави їх поділу на публічні та приватні доходи.

Досліджено основні види парафіскалітетів, визначено їхні ознаки: обов'язковість; иільовий характер платежу; спрямування коштів на иілі, пов'язані із задоволенням публічного фінансового інтересу; компенсаційний, однак безеквівалентний характер платежу; обов'язок щодо збирання коштів покладається на юридичних осіб, задіяних у реалізаиї̈ публічних функцій; назву платежу, як правило, закріплено в законі, а механізм його сплати врегульовано в підзаконному нормативно-правовому акті.

Визначено проблемні питання, що ускладнюють кваліфікачію таких платежів у складі публічних доходів. Акцентовано увагу на питанні балансу публічного і приватного інтересів у діяльності юридичних осіб під час справляння ними обов'язкових платежів у зв'язку з виконанням публічних функиій економічного і соиіального характеру. Неподаткові надходження до фондів юридичних осіб публічного і приватного права спрямовуються як на задоволення потреб та інтересів суспільства, так і дають змогу вирішувати питання, пов'язані безпосередньо з функиіонуванням юридичної особи - власника фонду коштів. Сформульовано висновки та практичні рекомендащії щодо вдосконалення правового регулювання неподаткових обов'язкових платежів до позабюджетних фондів. Доведено необхідність урегулювання на законодавчому рівні відносин щодо справляння публічних доходів та щодо визначення порядку встановлення неподаткових обов'язкових платежів.

Ключові слова: парафіскальні платежі, публічні фінанси, публічні фонди, публічні інтереси, квазіпублічні фонди, обов'язкові платежі, неподаткові доходи, позабюджетні фонди.

Постановка проблеми. Протягом останніх років у країні було проведено низку заходів, спрямованих на реформування податкової системи України. Однак вони не призвели до очікуваного збільшення надходжень до бюджетів. Для досягнення позитивних зрушень в економічному розвитку держави необхідно віднайти нові джерела доходів публічних фондів коштів (бюджету та позабюджетних фондів коштів), урегулювати питання залучення коштів юридичних осіб публічного та приватного права до виконання окремих публічних функцій. Вирішення цих завдань потребує вироблення чіткого механізму правового регулювання публічних доходів, визначення порядку вста- новлення та справляння обов'язкових платежів на користь юридичних осіб, залучених до виконання окремих публічних функцій.

Правовим питанням функціонування неподаткових обов'язкових платежів на відміну від податків традиційно приділяється незначна увага з боку як науковців, так і законодавця. Окремі аспекти механізму їх правового регулювання розглядали у своїх працях українські вчені А.А. Нечай, О.А. МузикаСтефанчук, Н.Я. Якимчук, Є.С. Маринчак. Зокрема, було досліджено сутність та систему неподаткових обов'язкових платежів до місцевих бюджетів, запропоновано концепцію квазіпублічних фондів коштів, розглянуто види фіскальних неподаткових 
платежів до бюджетів тощо. Питання встановлення, справляння та класифікації обов'язкових платежів, що зараховуються до фондів коштів юридичних осіб публічного чи приватного права, яких залучено державою до реалізації публічних функцій економічного та соціального спрямування, залишаються сьогодні недостатньо дослідженими українськими науковцями.

Метою статті є характеристика правової природи неподаткових обов'язкових платежів на користь юридичної особи публічного чи приватного права, визначення місця цих платежів у системі публічних доходів, з'ясування прогалин у чинному законодавстві щодо їх правового регулювання та вироблення рекомендацій щодо їх усунення.

Виклад основного матеріалу. Слід розрізняти неподаткові платежі до бюджету та неподаткові платежі до інших фондів коштів. Серед останніх розрізняють дві групи: платежі до позабюджетних централізованих фондів коштів та до фондів юридичних осіб приватного і публічного права. Платежі другої групи в багатьох наукових джерелах та в законодавстві окремих країн розглядаються під назвою «парафіскалітети», «парафіскальні платежі». Однак зразу слід акцентувати увагу на тому, що український законодавець не оперує подібними термінами, а науковці не мають єдиної думки щодо складу платежів, які охоплюються поняттям «парафіскалітетні платежі».

Французький учений Поль Годме характеризував цю групу доходів як обов'язкові платежі на користь юридичних осіб публічного чи приватного права, що не є державою, місцевими органами та їх адміністративними установами, встановлені в економічних чи соціальних інтересах [1, с. 377].

Серед учених різних країн відсутня єдина позиція щодо кваліфікації того чи іншого платежу як парафіскалітету. Відсутні чіткі критерії розмежування парафіскалітетів та квазіподатків. До останніх відносять неподаткові обов'язкові платежі до бюджету та в окремих випадках - і платежі до позабюджетних фондів. Одні науковці пропонують включати до парафіскалітетів усі платежі, що надходять до позабюджетних фондів, у тому числі й так звані «квазіподатки». Інші до цієї групи включають лише ті платежі, які надходять до фондів коштів юридичних осіб приватного і публічного права. Однак низка платежів, наприклад платежі до Фонду гарантування вкладів фізичних осіб, в одному випадку називають у складі парафіскалітетів, в іншому у складі квазіподатків.
В Україні загальний порядок сплати таких платежів на законодавчому рівні не врегульовано. Щодо кожного 3 них діє відмінний механізм регулювання, притаманний лише даному конкретному платежу. Вони не мають законодавчо встановленої узагальнюючої назви і включаються або до групи неподаткових обов'язкових платежів, або прирівнюються до оплати послуг та знаходяться поза межами фінансово-правового регулювання.

Якщо в нашій країні дискусія щодо належності даних доходів до публічних розпочалася кілька років тому, то в країнах Західної Свропи справляння цих платежів чітко врегульовано законодавством та визначено їх місце в системі публічних доходів. Найбільше уваги правовому регулюванню парафіскалітетів було приділено у Франції. Серед науковців, що досліджували питання парафіскалітетів, були французькі учені Поль Годме, Жюльен Лаферрьєр та ін. [1, с. 377-381].

Франція стала однією 3 перших країн, яка на законодавчому рівні розробила правовий механізм справляння парафіскалітетів. Вимоги щодо їх встановлення було закріплено в ст. 4 Ордонансу № 59-2 від 2 січня 1959 р., де зазначалося, що «парафіскальні збори (les taxes parafiscales), які справляються на користь юридичної особи публічного чи приватного права ... 3 метою задоволення економічного чи соціального інтересу, встановлюються декретом за висновком Державної Ради на підставі доповіді міністра фінансів та зацікавленого міністра». Дозвіл на їх справляння повинен щорічно підтверджуватися законом про фінанси. Відповідно до ст. 32 вказаного Ордонансу, щорічно до проєкту закону про фінанси додають список парафіскалітетів [2]. Парафіскалітети існують і в інших країнах, однак відрізняються за назвою. У Німеччині застосовують термін Sozialversicherungsbeitrag (спеціальні збори, особливі платежі»), в Іспанії - parafiscalidad.

Незважаючи на те що науковці Франції були одними з фундаторів доктрини про даний платіж, на початку XXI ст. ця країна переглядає своє фінансове законодавство i, відповідно до Органічного закону про фінанси від 1 серпня 2001 р. № 2001-692 [3], обмежує застосування терміна «парафіскалітетні платежі» та звужує коло доходів, які підпадали під відповідний правовий режим. Французький законодавець починає оперувати іншим поняттям - платежі будь-якого роду, що справляються на користь третіх осіб (відмінних від держави) з метою виконання ними публічних завдань. Дозвіл на їх справляння має міститися у щорічному акті про фінанси. 
Платежі, подібні до парафіскалітетів, існують і в нашій країні. I з кожним роком їх кількість зростає. Кошти надходять до фондів юридичних осіб публічного і приватного права, які залучені державою до реалізації публічних функцій (економічної чи соціальної функції) та здійснюють діяльність, спрямовану на задоволення публічного інтересу. Під час реалізації юридичною особою зазначених функцій відбувається поєднання публічного і приватного інтересів. Якщо ще кілька років тому фінансовоправова наука оперувала лише поняттям «публічний інтерес», розкриваючи зміст публічної фінансової діяльності, то сьогодні піднімаються питання поєднання та досягнення балансу публічного i приватного інтересів у процесі реалізації фінансовоправових норм, «про взаємопроникнення публічного і приватного інтересів у процес публічної фінансової діяльності» [4, с. 8]. Ці положення знайшли своє обгрунтування в працях М. Кармаліти (Приватний і публічний інтерес у системі податкових правовідносин : монографія. 2019), В. Чайки (Податкова політика України: теоретико-правовий аспект : монографія. 2017) та ін.

Неподаткові надходження до фондів юридичних осіб публічного і приватного права спрямовуються як на задоволення потреб та інтересів суспільства, так і лають змогу вирішувати питання, пов'язані безпосередньо 3 функціонуванням юридичної особи - власника фонду коштів. М.В. Кармаліта, досліджуючи питання співвідношення приватних та публічних начал у процесі застосування норм податкового права, звертає увагу на дуалізм завдань і цілей під час реалізації в оподаткуванні приватного і публічного інтересів [4, с. 8].

Аналізуючи українське законодавство, можемо виділити групу платежів, які відповідають характеристикам, наведеним у зарубіжному законодавстві та іноземних наукових джерелах щодо парафіскалітетів. До цієї групи включаємо обов'язкові платежі на користь юридичних осіб приватного і публічного права, які встановлено державними органами 3 метою покриття витрат таких юридичних осіб на виконання ними публічних функцій економічного та соціального спрямування. До таких платежів належать: 1) портові збори, що справляються відповідно до ст. 22 Закону України «Про морські порти» (крім портового (адміністративного) збору, який зараховується до Державного бюджету України) [5]; 2) плата за аеронавігаційне обслуговування, що справляється відповідно до ст. 36 Повітряного кодексу України [6]; 3) страхові платежі, що сплачу- ються страхувальником відповідно до укладених договорів обов'язкового страхування, наприклад відповідно до Закону України від 1 липня 2004 р. № 1961-IV «Про обов'язкове страхування цивільно-правової відповідальності власників наземних транспортних засобів» [7]; 4) збори до Фонду гарантування вкладів фізичних осіб тощо.

Фонд гарантування вкладів фізичних осіб має подвійну правову природу. По-перше, він є юридичною особою публічного права, що виконує спеціальні функції у сфері гарантування вкладів фізичних осіб та виведення неплатоспроможних банків із ринку і ліквідації банків у випадках, установлених Законом України від 23.02.2012 № 4452-VI «Про систему гарантування вкладів фізичних осіб». По-друге, це позабюджетний фонд коштів, джерелами формування якого, серед інших доходів, є й обов'язкові платежі, які зобов'язані сплачувати учасники Фонду (початкові збори, регулярні збори, спеціальний збір) [8]. Установа банку, отримавши в Національному банку України банківську ліцензію, в обов’язковому порядку набуває статусу учасника Фонду гарантування вкладів фізичних осіб та, відповідно, не може відмовитися від сплати перелічених вище зборів. Згідно зі ст. 20 указаного Закону, кошти Фонду не включаються до державного бюджету України, не підлягають вилученню і спрямовуються на: виплати гарантованої суми відшкодування вкладникам коштів за вкладами; погашення облігацій і виплату доходів за ними (сплата векселів), ураховуючи витрати, пов'язані з їх розміщенням (видачею); покриття витрат, пов'язаних із залученими Фондом кредитами, тощо.

Із прийняттям Закону України «Про ринок природного газу» [9] починаючи з 2020 р. було запроваджено новий платіж - плату за розподіл газу, який за своїми рисами відповідає ознакам неподаткового обов'язкового платежу, що сплачується на користь юридичної особи публічного чи приватного права (в нашому разі - на користь операторів газорозподільних мереж). Плата за розподіл газу не є оплатою споживача за спожитий протягом звітного періоду обсяг природного газу. Це самостійний вид платежу, який установлений відповідно до ст. 40 вказаного вище Закону та деталізовано в актах Національної комісії, що здійснюе державне регулювання у сферах енергетики та комунальних послуг (далі - НКРЕКП) а саме в Кодексі газорозподільних систем [10] та Типовому договорі розподілу природного газу [11]. Плату за розподіл газу сплачують особи - споживачі природного газу, яких приєднано до газової мережі, неза- 
лежно від того, чи використовували вони газ за звітний період чи ні. Так, відповідно до п. 9 гл. 6 розділу VI Кодексу газорозподільних систем, «припинення або обмеження розподілу (споживання) природного газу не звільняє споживача від зобов'язання оплати вартості послуг за договором розподілу природного газу, крім випадку розірвання цього договору або внесення змін до заяви-приєднання...» [10]. Розмір плати розраховується виходячи з тарифів, установлених НКРЕКП для операторів газорозподільних систем. Кошти, що надходять від цього платежу на рахунки операторів ГТМ, спрямовуються на обслуговування газотранспортних мереж.

Серед неподаткових платежів як складової частини публічних доходів слід розглядати й платежі, що сплачуються відповідно до Закону України «Про авторське право і суміжні права». Цій групі платежів також притаманні риси, які дають змогу включити їх до «парафіскалітетів». Відповідно до ч. ч. 5 та 6 ст. 12 Закону України «Про ефективне управління майновими правами правовласників у сфері авторського права і (або) суміжних прав» [12], збирання винагороди з користувачів у сферах обов'язкового і розширеного колективного управління здійснюється акредитованими організаціями колективного управління, що $є$ громадськими об'єднаннями зі статусом юридичної особи, не мають на меті отримання прибутку, засновані виключно правовласниками, діяльність яких «спрямована на колективне управління майновими правами на об'єкти авторського права і (або) суміжних прав» (ст. 1 Закону). Ці організації, відповідно до ст. 20 указаного Закону, здійснюють збирання винагороди 3 користувачів згідно зі сферою, за якою організація зареєстрована i (або) акредитована та внесена до Реєстру організацій колективного управління. Наприклад, серед таких сфер законодавець називає: право слідування щодо творів образотворчого мистецтва; репрографічне відтворення творів та їх частин (уривків); «відтворення в домашніх умовах і в особистих цілях творів, виконань, зафіксованих у фонограмах, відеограмах, їх примірниках, а також аудіовізуальних творів та їх примірників тощо.

Серед організацій колективного управління, що пройшли акредитацію, - Громадська спілка «Українська ліга авторських та суміжних прав», Громадська спілка «Український музичний альянс» та ін. Остання 3 них акредитована здійснювати збір і розподіл винагороди (відрахувань) для компенсації втрат правовласників від приватного копіювання (відтворення в домашніх умовах і в особистих цілях творів і виконань, зафік- сованих у фонограмах, відеограмах, а також аудіовізуальних творах). Розміри відрахувань сьогодні встановлено у відсотках від фактурної вартості (вартості обладнання і матеріальних носіїв, із застосуванням яких можливо здійснити таке відтворення) виробленого/імпортованого товару (смартфону, планшету, ноутбуку тощо), однак у найближчий час вони мають бути переглянуті відповідно до вимог ст. 20 Закону, в якій виписано нову процедуру встановлення ставок (тарифів) винагороди за використання авторського права і суміжних прав.

Виникає логічне питання, чи є підстави розглядати кошти, що надходять до грошових фондів юридичних осіб приватного і публічного права, різновидом публічних доходів. Цікаву позицію обгрунтовує М.В. Карасьова. Називаючи основним критерієм під час характеристики публічних фінансів критерій «забезпечення публічного інтересу», учена однозначно стверджує, що парафіскалітети входять до складу публічних доходів. М.В. Карасьова зазначає, що під публічними фінансами можемо розуміти грошові відносини, які опосередковують різні за формою власності грошові фонди, але забезпечують в кінцевому підсумку лише публічні інтереси, визначені й урегульовані державою і муніципальними утвореннями. До публічних фінансів підпадають і відносини, які виникають у ході фінансової діяльності інших (недержавних суб'єктів), які реалізують публічні інтереси в силу завдань, покладених на них державою [13, с. 191].

Дещо інша позиція висловлена А.А. Нечай. Належність фонду до публічного чи приватного учена пропонує визначати за п'ятьма критеріями: 1) форма власності на грошові кошти; 2) характер інтересу, який проявляється у правовідносинах; 3) мета виникнення відповідних суспільних відносин; 4) метод правового регулювання суспільних відносин; 5) форма розподілу i форма використання грошового фонду. Застосовуючи зазначені критерії для аналізу низки фондів (фондів приватних страхових організацій, за рахунок яких забезпечуються різні види державного обов'язкового особистого страхування та обов'язкового страхування відповідальності, встановленого законом для певних груп осіб та/або видів діяльності тощо), учена дійшла висновку, що такі фонди «мають «розмитий» (невизначений) правовий статус: за деякими критеріями вони належать до публічних грошових фондів (а отже, повинні регулюватися імперативними нормами фінансового права на всіх етапах свого існування), а за іншими мають властивості приватних фондів (тобто 
повинні регулюватися нормами господарського та цивільного права)» [14, с. 238-239]. Грошові фонди, які мають ознаки як приватних, так і публічних грошових фондів, А.А. Нечай визначає як квазіпублічні фонди [14, с. 238]. Така наукова позиція заслуговує на увагу. Але чи є у нас підстави робити висновок, що і кошти, які надходять до таких фондів мають визначатися як «квазіпублічні доходи»? Кошти, які зараховуються до квазіпублічних фондів, мають різну правову природу та призначення. Особливістю даних фондів буде поєднання в них приватних і публічних доходів. Частина доходів - це кошти, які буде спрямовано юридичною особою відповідно до чинного законодавства на реалізацію завдань у межах виконання нею економічної чи соціальної функції з метою задоволення публічного інтересу. Такі доходи слід розглядати як публічні. Саме до них і застосовують поняття «парафіскалітети». Усі інші надходження до квазіпублічних фондів слід розглядати як приватні доходи.

Серед ознак обов'язкових платежів, що справляються на користь юридичних осіб приватного і публічного права, які залучені до реалізації публічних функцій економічного і соціального спрямування («парафіскалітетні платежі»), слід виділити такі: 1) це платежі, що завжди мають цільовий характер. Вони спрямовуються на вирішення певних соціальних чи економічних завдань із метою задоволення публічного інтересу; 2) на відміну від податків, які є індивідуально безоплатними платежами, парафіскалітети наділені рисами компенсаційності. Однак не йдеться про еквівалентність платежу; 3) на відміну від неподаткових обов'язкових платежів до бюджету (наприклад, плата за адміністративні послуги, де послугу надає державний орган чи орган місцевого самоврядування) під час збирання (сплаті) парафіскалітетів ні державні органи, ні органи місцевого самоврядування не є учасниками даних правовідносин. Збір коштів покладається на юридичних осіб, задіяних у реалізації економічної чи соціальної функції держави; 4) назву платежу, як правило, закріплено в законі, а механізм його сплати врегульовано в підзаконному нормативноправовому акті.

\section{Висновки}

Проведене дослідження неподаткових обов'язкових платежів до позабюджетних фондів, у тому числі платежів на користь юридичних осіб публічного чи приватного права, що залучені державою до виконання публічних функцій економічного та соціального спрямування, дає змогу зробити такі висновки. Необхідно на законодавчому рівні врегулювати відносини щодо справляння публічних доходів; визначити місце обов'язкових платежів на користь юридичних осіб публічного чи приватного права у зв'язку 3 виконанням ними публічних функцій економічного і соціального спрямування, що мають на меті задоволення публічного інтересу (парафіскалітетів) у складі публічних доходів; з урахуванням зарубіжного досвіду виробити чіткі правила встановлення та справляння даних платежів.

\section{Список використаних джерел:}

1. Годме П.М. Финансовое право / пер. с франц. Москва : Прогресс, 1978. 429 с.

2. Ordonnance $\mathrm{n}^{\circ} 59-2$ du 2 janvier 1959 portant loi organique relative aux lois de finances. URL: https://www.legifrance.gouv.fr/jorf/id/ JORFTEXT000000339591 (дата звернення: 24.04.2021).

3. Loi organique $\mathrm{n}^{\circ}$ 2001-692 du 1 aot 2001 relative aux lois de finances. URL: https:// www.legifrance.gouv.fr/loda/id/LEGIA RTI000006321099/2005-01-01/ (дата звернення: 24.04.2021)

4. Кармаліта М.В. Правове забезпечення реалізації приватного та публічного інтересу в оподаткуванні : автореф. дис. ... канд. юрид. наук. Ірпінь, 2020. 40 c.

5. Про морські порти : Закон України від 17.05.2012 № 4709-VI. URL: https://zakon.rada. gov.ua/laws/main/4709-17 (дата звернення: 24.04.2021).

6. Повітряний кодекс України : Закон України від 19.05.2011 № 3393-VI. URL: https://zakon. rada.gov.ua/laws/main/3393-17 (дата звернення: 24.04.2021).

7. Про обов'язкове страхування цивільно-правової відповідальності власників наземних транспортних засобів : Закон України від 01.07.2004 № 1961-IV. URL: https://zakon.rada.gov.ua/laws/ show/1961-15\#Text (дата звернення: 24.04.2021).

8. Про систему гарантування вкладів фізичних осіб: Закон від 23.02.2012 № 4452-VI. URL: https:// zakon.rada.gov.ua/laws/show/4452-17\#Text (дата звернення: 24.04.2021).

9. Про ринок природного газу : Закон України від 09.04.2015 № 329-VIII. URL: https://zakon.rada.gov.ua/laws/show/329-19\#Text (дата звернення: 24.04.2021).

10. Типовий договір розподілу природного газу : Постанова НКРЕКП від 30.09.2015 № 2498. URL: https://zakon.rada.gov.ua/laws/ show/z1384-15\#n14 (дата звернення: 24.04.2021).

11. Кодекс газорозподільних систем : Постанова НКРЕКП від 30.09.2015№ 2494. URL: https:// zakon.rada.gov.ua/laws/main/z1379-15\#Text (дата звернення: 24.04.2021).

12. Про ефективне управління майновими правами правовласників у сфері авторського права і (або) суміжних прав : Закон України від 
15.05.2018 № 2415-VIII. URL: https://zakon.rada. gov.ua/laws/show/2415-19\#Text (дата звернення: 24.04.2021)

13. Карасева М.В. О предмете финансового права в современных условиях. Вестник Воро- нежского государственного университета. Серия «Право». 2019. № 4. С. 187-199.

14. Нечай А.А. Правові питання визначення, класифікації та регулювання квазіпублічних грошових фондів. Право Украйни. 2016. № 3. С. 236-243.

Nadiia Pryshva. Debatable issues of the legal regime of non-tax mandatory payments to extrabudgetary funds

The article studies non-tax mandatory payments to extrabudgetary funds and defines the main types of such payments. Particular attention is devoted to the payments that are categorized as parafiscal charges in scientific sources. The latter include mandatory payments established by the state, which are credited to the funds of legal entities of public or private law, engaged by the state for implementation of economic and social public functions. The legal nature of payments to the Deposit Guarantee Fund, remuneration (deductions) for compensation of losses incurred by the right holders as a result of private copying, gas distribution fees, etc. is considered.

The article considers the role of parafiscal charges within the system of public revenue streams, income of quasi-public funds, the bases of their division into public and private income.

The main types of parafiscal charges are investigated. Their main features are defined - purposefulness of the payment; directing funds to goals related to the satisfaction of public financial interest; compensatory, but non-equivalent nature of the payment; the obligation to raise funds is vested with legal entities involved in the implementation of public functions; the name of the payment is typically fixed in the law, while the mechanism of its payment is regulated in bylaws.

Problematic issues have been identified that complicate the qualification of such payments as part of public revenue streams. Emphasis is placed on the issue of the balance of public and private interest in the business of legal entities while charging mandatory payments related to the performance of public functions of economic and social nature.

Non-tax revenues of legal entities of public and private law are aimed at fulfillment of the needs and interests of society while allowing addressing issues directly related to the functioning of the legal entity the fund manager. The article provides conclusions and practical recommendations for improving the legal regulation of non-tax mandatory payments to extrabudgetary funds. The need to regulate the relations concerning the collection of public revenue streams at the legislative level and determining the procedure for establishing non-tax mandatory payments is substantiated.

Key words: parafiscal charges, public finances, public funds, public interests, quasi-public funds, mandatory payments, non-fiscal income, extrabudgetary funds. 